tensive. When collateral crimes, within the privilege under the English rule, are relevant to the issues, the other scope rules will be wider than this rule of waiver. To permit the prosecution to bring out collateral crimes on cross-examination, in conformity with these scope rules, would be in violation of the English rule of waiver.

An extreme rule states that the accused waives his privilege entirely by his appearance on the witness stand and that questions about collateral criminal acts can be asked for the sole purpose of impeachment. ${ }^{25}$ All scope rules concur in allowing impeachment upon cross-examination. ${ }^{26}$ The separate rules governing ordinary impeachment are added to the two sets of rules already discussed and may temper the effect of this rule by an influence upon the interpretation of the formula. For example, the New York rule against impeachment by degrading questions ${ }^{27}$ may well operate to exclude evidence otherwise admissible under the extreme waiver rule. Yet the ever present danger that the rules governing impeachment may be submerged in the application of the statutory formula may make the appearance of the criminal defendant on the stand in his own behalf too dangerous to be risked. Impeachment by independent criminal acts is apt to result in conviction of the defendant as a tax evader for murder.

The English statutory rule of waiver should obtain the most desirable result, for it will exclude the danger of conviction upon collateral matters and yet require waiver wide enough to make possible the disclosure of half-truths by cross-examination. ${ }^{28}$ That this rule is not co-extensive with any scope rule in every set of facts has already been shown. A satisfactory disposition of the problem can only be reached, however, if the courts keep in mind that the doctrine of waiver is entirely separate from that of scope and that a forced connection of the two leads only to ambiguity.

\title{
DISTRIBUTION OF THE PROCEEDS FROM A DELAYED SALE OF UNPRODUCTIVE TRUST INVESTMENTS-NEW FORMULAS FOR OLD
}

When property settled in trust for successive beneficiaries is or becomes wholly or partly unproductive, and there is a sale only after a reasonable delay, the trustee is faced with the problem of equitably distributing the sale proceeds.

${ }^{25}$ State v. Griffin, $20 I$ N. Car. 54I, I6o S.E. 826 (I93I); People v. Webster, I39 N.Y. 73, 84 (1893). The general view seems to be that there is no waiver of the privilege in regard to independent crimes when they are used merely for impeachment purposes. Clapp v. State, 94 Tenn. I86, 30 S.W. 214 (I895); State v. Banks, 258 Mo. 479, I67 S.W. 505 (I9r4). Cf. State v. Pancoast, 5 N.D. 5I6, 55I, 67 N.W. I052, 1062 (I896).

${ }^{26} 2$ Wigmore op. cit. supra note $6 \S 9 \mathrm{I} 4$.

${ }_{27}$ Lohman v. People, I N.Y. 379 ( 1848 ). This rule remains only in a few jurisdictions. 2 Wigmore op. cit. supra note 6 § gr4. Cf. State v. Rozum, 8 N.D. 548,80 N.W. 477 (r899), where the court held that degrading questions would be allowed.

${ }^{28}$ It is true that the English rule prevents the showing of preparatory crimes on cross-examination, but these crimes, since relevant to the issues of the case, may be proved by independent witnesses. See 4 Wigmore, op. cit. supra note $6, \S 2277$. 
The source of the difficulty in such cases is the fact that during the interval of unproductivity, which may run into several years, the life-tenant has received very little or no income. Several factors-the varying nature of the res, the fluctuations in its value, and the presence of taxes, carrying charges, and whatever income has actually been produced-combine to make the problem a perplexing one. The frequency of the problem during the depression has produced a number of cases, ${ }^{x}$ some uniform legislation, ${ }^{2}$ and a not inconsiderable amount of commentary. ${ }^{3}$ Nevertheless, neither the results reached at present nor the rationale offered are entirely satisfactory.

The intention of the settlor might seem to afford the best answer to the double question: should the life-tenant receive a share of the proceeds and if so, how large a share? It is clear that the settlor might expressly provide that there be no apportionment of the proceeds between the two beneficiaries or that there be apportionment in a given ratio, however arbitrary. 4 But in the absence of express intention, he seems to have intended three incompatible results: first, that the life tenant of whom he is often said to be especially solicitious ${ }^{5}$ get in-

× During the interval from 1929 to 1937 more than twelve cases have been reported. It should be noted that the amount of actual litigation does not reflect the frequency of the problem since a rule designed primarily for the guidance of trustees can be established with an economy of cases.

2 Uniform Principal and Income Act $\$$ II, 9 U.L.A. (Sup. 1936) r96. The Act has been enacted in Oregon and Virginia; Ore. Code Supp. I935, $\$ \S 63-1201$ to 63-1214, Va. Laws I936, c. 432 .

34 Bogert, Trusts and Trustees $\$ 825$ ff. (1935); Rest., Trusts $\S 240$ (1935); Brandis, Trust Administration: Apportionment of Proceeds of Sale of Unproductive Land and of Expenses, 9 N.C.L. Rev. I 27 (193I); Bailey and Rice, Duties of a Trustee with Respect to Defaulted Mortgage Investments, 84 U. of Pa. L. Rev. (r935); Farb, Distribution of Proceeds on Sale of Properties under Foreclosed Mortgages, 57 Trust Companies 245 (r933); Note, 40 Yale L.J. 275 (1930); Note, 49 Harv. L. Rev. 806 (I936).

${ }_{4} 4$ Bogert, Trusts and Trustees $\$ 827$ (1935). "The life beneficiary is not entitled to compel a sale nor to share in the proceeds of the sale if it is expressly or impliedly provided otherwise by the terms of the trust," Scott, Cases on Trusts 576, n. I (2d ed. I93I). The same result has been reached where retention of the unproductive property has been authorized. 49 Harv. L. Rev. 895, 806, n. 2 (1936); Green v. Crapo, 18I Mass. 55 (I902); Jordan v. Jordan, I92 Mass. 24I, 78 N.E. 459 (r906); Martin v. Kimball, 86 N.J. Eq. I69 (I916); York v. Maryland Co., I49 Md. 608 (1926). See also Creed v. Connolly, 272 Mass. 24I, 172 N.E. ro6 (r930) (lack of specific direction to convert and the absence of extraneous evidence of conversional intent held to indicate that the testator intended no apportionment), 40 Yale L. J. 275 (1930). Similarly, the intention of the settlor will carry all the income produced by a hazardous or wasting asset to the life beneficiary, although ordinarily he is entitled only to the normal trust yield and the excess is treated as principal. Frankel v. Farmers' Loan and Trust Co., 152 App. Div. 58, 136 N.Y. Supp. 703 (IgI2), aff'd 209 N.Y. 593, ro3 N.E. II24 (I9r3); Gray v. Siggers, r5 Ch. Div. 74 (I880); Matter of James, I46 N.Y. 78 (1895), Rhode Island Trust Co. v. Bradley, 4I R.I. I74, I03 Atl. 486 (rgr8).

5 Bogart, Trusts and Trustees $\S 826$, n. 74 (I935). "The settlor is presumed to have more interest in the life tenant than in the remainderman, since the former generally is a near relative and the latter are usually more remote or unascertained persons." In re Martens, 39 N.Y. Supp. r89, I6 Misc. 245. (ז896). See also Lawrence v. Littlefield, 215 N.Y. 56r, Iog N.E. $6 \mathrm{rr}$ (I9r5); Furniss v. Cruikshank, 230 N.Y. 495, r30 N.E. 625 (r92x). See infra, note to. 
come steadily; second, that the integrity of the corpus be preserved; and finally, that the trustee convert the unproductive investment opportunely rather than immediately and at a sacrifice. To say this, however, is really equivalent to saying that the settlor has not really thought about the problem at all. Since, then, his intent is fatally ambiguous or totally non-existent, any attempt to execute his intention will in reality amount to applying a rule of law.

The classic rule of law in these cases has been to find what sum if invested at the beginning of the interval of unproductivity would with the income measured at the normal trust rate equal the amount of the sale proceeds, and to treat the sum so found as principal. ${ }^{6}$ This rule is based on the doctrine of equitable conversion. The trustee had a duty to convert into a productive investment immediately; the property will be treated as though he had in fact so converted. ${ }^{7}$

The discussion in the cases has centered on the problem of whether the trustee had a duty to convert immediately. ${ }^{8}$ The solution of this problem, in keeping with orthodox notions of equitable conversion, has been sought in the intent of the settlor. Thus, if there is an express imperative direction to sell, the rule of apportionment is almost uniformly applied.9 Where, however, the power of sale is not expressly mandatory, and this is the typical set-up, the courts have

${ }^{6}$ It is generally agreed that this procedure stems from the decision of Lord Eldon in Howe v. Earl of Dartmouth, 7 Ves., Jr. I27 (1802). The case involved neither a trust nor unproductive property; the property involved was overproductive and there was a duty to convert; the mechanics of apportionment were properly used to find what the normal income would have been. It is not entirely clear how this method, clearly appropriate to the case of overproductive property, was carried over to the cases of underproductive property.

7 See infra note 9 .

${ }^{8}$ Note, 40 Yale I. J. 275 (I930); Brandis Trust Administration: Apportionment of Proceeds of Sale of Unproductive Land and of Expense, 9 N.C. L. Rev. I27 (193I). See Edwards v. Edwards, 183 Mass. 58I, 67 N.E. 658 (I903); Furniss v. Cruikshank, 230 N.Y. 495, 130 N.E. 625 (I921); Matter of Satterwhite, 262 N.Y. 339, I86 N.E. 857 (I933); Creed v. Connelly, 272 Mass. 24I, I72 N.E. 106 (I930).

9 If the sale and reinvestment can be immediate, the life tenant is adequately protected without occasioning an invasion of the remainderman's interest. From this it is but a short and traditional step to a fictitious sale and reinvestment which are treated as having occurred immediately, or occasionally in testamentary trusts, one year later. In Matter of Satterwhite's Will, 262 N.Y. 339, I86 N.E. 857 (I933). Pound, J. summarized a typical position of a court in these cases as follows: "If the language of the will indicates an intention of the testator to constitute an imperative power of sale and an equitable conversion of the real estate into personalty at the time of the testator's death, it must be presumed that while the trustees were converting the real estate into personalty the right of the life tenant to income was the same as if the fund had come into existence immediately after the testator's death." See also Edwards v. Edwards, 183 Mass. 581, 67 N.E. 658 (I903); of. Taylor v. Clark, I Hare I6I (I84I) where Wigram, C. J., said: "The court acting upon a general rule feigns the property to be converted, as directed by the testator, at the end of one year from his death, and, at least from that time, gives to the tenant for life the precise income which would be produced if the property were actually so converted, and in its proper state of investment." See Furniss v. Cruikshank, 230 N.Y. 495, I30 N.E. 625 (I92I); 2 Perry, Trusts and Trustees $\S 549$ (7th ed. r929). The settlor may himself fix the time of conversion. Matter of Satterwhite, 262 N.Y. 339, I86 N.E. 857 (r933). 
found it necessary to weigh other factors in order to find a duty to convert. Thus, courts have considered the degree of kinship to the settlor of the beneficiaries $;{ }^{10}$ what proportion of property in trust was unproductive $;^{1 \mathrm{II}}$ and whether the property was unproductive from the inception of the trust or only became so subsequently..$^{12}$ But it would seem that even under a mandatory power of sale the trustee has discretion as to when to sell ${ }^{13}$ and even under a discretionary power he must convert an unprofitable investment ${ }^{\mathrm{x}}$-hence the distinction be-

ro In Furniss v. Cruikshank, 230 N.Y. 495, I30 N.E. 625 (I92x), a power of sale was construed as mandatory though expressly defined as discretionary when testator's wife and children held the life interest. In In re Rowland's Estate, 273 N.Y. 100, 6 N.E. (2d) 392 (1937), the same result was reached under similar facts even though the property became unproductive after the creation of the trust. In re Martens, 39 N.Y. Supp. I89, I6 Misc. 245 ( 1896 ); $c f$. Creed v. Connelly, 272 Mass. 24I, I72 N.E. Io6 (I930); commented on in Note, 40 Yale L. J. 275 (r93o).

II If the predominance of unproductive property deprives the life beneficiary of virtually all income, the power of sale will almost certainly be interpreted as a mandatory one, working an equitable conversion. See Furniss v. Cruikshank, 230 N.Y. 495 , I3o N.E. 625 (I921); Lawrence v. Littlefield, 215 N.Y. 56r, rog N.E. 6rI (I9r5); Edwards v. Edwards, I83 Mass. 581, 67 N.E. 658 (1903); Spencer v. Spencer, 2I9 N.Y. 459, II4 N.E. 849 (I9I 7). Similarly, if the life tenant will receive substantially less than the testator intended, this interpretation is adopted. Ogden v. Allen, 225 Mass. 595, II4 N.E. 862 ( $\mathrm{IgI}_{7}$ ) (testator directed that widow receive $\$ 4,000$ annually). In In re Marshall's Estate, 136 Misc. II6, 238 N.Y. Supp. 763 (I930) apportionment was denied when the value of unproductive realty was $\$ 45,000$ and the value of the entire trust fund $\$ 1,000,000$. See also Creed v. Connelly, 272 Mass. 241, I72 N.E. Io6 (1930) (refusal to apportion partly because of small percentage of unproductive property); $c f$. Green v. Crapo, I8I Mass. 55, 62 N.E. 956 (I902); Jordon v. Jordon, I92 Mass. 337, 78 N.E. 459 (1906).

12 This distinction was repudiated in the most recent apportionment case, In re Rowland's Estate, 273 N.Y. 100, 6 N.E. (2d) 393 (1937). But see 49 Harv. L. Rev. 805 (I936).

${ }^{x_{3}} 4$ Bogert, Trusts and Trustees $\S 825$ (r935); Ogden v. Allen, 225 Mass. 595, II4 N.E. 862 (IgI7); Edwards v. Edwards, 183 Mass. 58I, 67 N.E. 658 (I903). In Lawrence v. Littlefield, 2 I5 N.Y. 56r, I09 N.E. 6II (I9I5), Hiscock, J., said the fact that the power was imperative did not deprive the trustee or executor of some discretion as to time and manner of sale or insure against delay in conversion during which taxes would accumulate. The sale was approximately four years after the testator's death. In Furniss v. Cruikshank, 230 N.Y. 495, 130 N.E. 625 (x921), where power was construed to be mandatory and the property sold piecemeal at intervals from eleven to twenty-eight years after the duty to convert arose, Andrews, J., said; "he [settlor] did not require an immediate sale. Speculative conditions were in his mind. The property might increase in value. Probably it would. A sale today might result in a sacrifice. In this matter he rested on the judgment of the trustees. That judgment rightfully exercised might induce them to hold it for years."

${ }^{14}$ Apart from intent, since unproductive property, unless retention is authorized, is an improper trust investment, the duty to convert may arise under the general rule of law requiring trustees to convert improper investments. 4 Bogert, Trusts and Trustees $\$ 825$ (I935). "By what is called the rule of Howe v. Earl of Dartmouth, if there is a bequest of one's personal estate or of the residue thereof to be enjoyed by persons in succession, it is the duty of the trustee to convert so much of the property as is of a wasting or perishable nature or which is unproductive into permanent approved securities. See Ames, 49r"; Scott, Cases on Trusts 576, n. I (2d ed. I93I); Edwards v. Edwards, I83 Mass. 58r, 67 N.E. 658 (I903); Rhode Island Hospital Trust Co. v. Tucker, 52 R.I. 277, 160 465 (1932). 
tween the two powers hardly affords a basis for a difference in result. ${ }^{15}$ The frequency of reversals of the lower court's interpretation of the settlor's intention on this point bears eloquent testimony to the arbitrary quality of the distinction. ${ }^{16}$ It is significant that both the Restatement of Trusts ${ }^{17}$ and the Uniform Principal and Income Act ${ }^{18}$ and even a recent case ostensibly applying the common law ${ }^{\text {r9 }}$ have abandoned the intention idiom and simply apply a rule of law that in the absence of intention to the contrary, there is a duty to convert and consequently there should be an apportionment.

The Restatement has further suggested a convenient formula for the mechanics of apportionment under the traditional rule. ${ }^{20}$ Thus, let $x=$ the sum to be found; $r=$ rate of income; $t=$ interval of unproductivity, $S=$ sale proceeds. Then:

$$
\begin{gathered}
x+x r t=S, \\
x(\mathrm{I}+r t)=S, 2 \mathrm{r} \\
x=\frac{S}{\mathrm{I}+r t} .
\end{gathered}
$$

Thus, the remainderman gets $S /(\mathrm{x}+r t)$; the life tenant $S-[S /(\mathrm{x}+r t)]$. But, even when the intention difficulty is put aside, and algebra is invoked, there remains a greater difficulty with the traditional approach. The rationale for the formula requires two palpably false propositions. First, it is based upon the trustee's failure to perform his duty to convert, equity treating as done what should have been done. But it is uniformly admitted that the trustee has not

Is In In re Jackson's Will, 258 N.Y. 28I, I79 N.E. 496, 500 (I932), Pound, J., said; "The distinction between this case and cases where there is no imperative power of sale or equitable conversion, where the testator directs the trustees to sell only in their discretion and where it is, therefore, said that the only inference is that the testator intended to benefit the principal of his estate may not ultimately prevail." But see In re Rowland's Estate, 273 N.Y. roo, 6 N.E. (2d) 393 ( 1937 ) where the same court persisted in verbally preserving the distinction. Cf. Matter of Chapal, 269 N.Y. 464 N.E. (I936) (apportionment of proceeds from defaulted trust mortgages without searching for an equitable conversion).

${ }^{16}$ Creed v. Connelly, 272 Mass. 24I, 172 N.E. Io6 (I930); Furniss v. Cruikshank, 230 N.Y. 495, I30 N.E. 625 (I92I); In re Rowland's Estate, 273 N.Y. roo, 6 N.E. (2d) 393 (I937); In re Jackson's Will, 258 N.Y. 28 I I79 N.E. 496 (1932); Lawrence v. Littlefield, 215 N.Y. 56r, Io9 N.E. 6II (I9I5). (I930).

${ }^{17}$ Rests., Trusts $\$ 240$ (I935). But see Creed v. Connelly, 272 Mass. 24I, I72 N.E. Io6

${ }^{18} 9$ U.L.A. (Supp. I936) I96, and see note, 40 Yale I. J. ${ }^{275}$ (I930).

${ }^{9}$ In re Rowland's Estate, 273 N.Y. 100, 6 N.E. (2d) 393 (1937). See also Rhode Island Hospital Trust Co. v. Tucker, 52 R.I. 277, x60 Atl. 465 (1935); cf. Hite v. Hite, 93 Ky. 257, 20 S.W. 778, I9 L.R.A. 173 (1892).

${ }^{20}$ Rest., Trusts $\$ 24 \mathrm{I}$, comment (e) (I935).

2x On this step and on the algebra used generally in the note see Rietz, Craythorne and Taylor, School Algebra: First Course (1900); of. Hart, Brief College Algebra (I936). 
violated any duty unless he fails to convert within a reasonable time. ${ }^{22}$ Hence, it is peculiar to treat as done that which need not have been done. Further, the burden of the loss thus occasioned would not seem to be put on the supposed wrongdoer, the trustee, but rather on the innocent remainderman. Second, it is based on the assumption that the property increased in value during the period of unproductivity by the amount of income which would have been produced had there been an immediate sale and reinvestment. ${ }^{23}$ Actually, it is much more likely that unproductive property decreases in value and certainly if it does increase it does so despite and not because it has been unproductive; finally, only by a strange coincidence ${ }^{24}$ would it increase precisely by the amount of income that would have been produced. Consequently, it is somewhat difficult to see why apportionment should be based on finding out what sum if invested at the current rate at the inception of unproductivity would equal the sale proceeds. ${ }^{25}$

Of course it is not contended that anyone has with complete literalness espoused so fictional an approach. But unfortunately once the fiction is taken away, the justification for apportionment in this ratio is by no means selfevident.

Under the traditional interpretation of the respective interests of the life

${ }_{22}$ Rest., Trusts $\$ 240$, comment (f) (I935). See cases cited supra note I3. In Creer v. McAleer, 275 Mass. 353, 775 N.E. 76r (193I), a trustee was surcharged for the loss incurred in retaining a wasting mining stock beyond a reasonable time. See, generally, Bogert, The Trustee's Duty to Convert Investments, I Univ. Chi. L. Rev. 28 (I933).

${ }^{23}$ Conceivably, the assumption might be that the subsequent unproductivity is an indication that the property was overvalued and that its real value had it been sold would have corresponded to the principal as derived by the formula. But there is no precise relation between unproductivity and the value in the sense of what the property could have been sold for at the inception of unproductivity. Further, such an assumption makes the equitable conversion, even more unsound since the trustee had a duty not to sell at a sacrifice.

${ }_{24}^{4}$ See, however, the example in 4 Bogert, Trusts and Trustees $\$ 825$ (1935).

${ }^{25}$ This difficulty apparently was shared by some members of the American Law Institute when $\$ \S 240,24 I$ were being considered:

Mr. Rose: ".... Now, there is in this proposition something that I absolutely cannot grasp. I have tried, and at night I prayed the Lord for guidance and $I$ am just as ignorant now as I was when I began. Of course, everything that is in this is perfectly intelligible to these learned gentlemen, but it is not for their benefit that this Restatement is being made. It is being made for people like me who need guidance. Now, if you will turn to page 84 , line 15 , you will find a statement about delayed resales of unproductive property. Where property has been held by the trustee for a rise so that the life tenant gets nothing at all and finally it is sold, what shall be done with the proceeds? Now, I have no doubt of the absolute accuracy of the rule laid down here, but the trouble is that I have not the slightest idea of what it is or how it can be worked out. . . . . I must say that I stand here as an oasis of ignorance in a desert of learning, and while I am alone in this learned body, I represent an enormous class. Mr. Lincoln justly said that God must love the common people because he made so many of them. Surely he must have loved the simple-minded country lawyers because he has made a world of them and there is not one of them that can make head or tail out of that rule." XI Proceedings: American Law Institute 206-7 (1934). Mr. Rose also expressed bewilderment at the algebra. 
tenant and the remainderman, it is not apparent why there should be any apportionment. If the life tenant gets whatever income is produced and the remainderman gets corpus per se, it would seem axiomatic that in the absence of income the life tenant get nothing. This is further supplemented by the consideration that the remainder bears the risk of changes in corpus ${ }^{26}$ and that consequently the life tenant should bear the risk of changes in income. Further, since the life tenant is frequently given excess income yielded by legal investments, ${ }^{27}$ it seems arbitrary not also to impose the burden of deficient income upon him. And finally it may be argued that conversion into productive property within a reasonable time is all the protection the life tenant is entitled to since this protection can be given without impairing the interest of the remainderman.

But it is suggested that there is a better view of the respective interests of the beneficiaries. They should be regarded not as "owning" the income and the corpus respectively, but rather as proportionately sharing the total net value arising from the property. ${ }^{28}$ Consider a normal case in which the corpus of $\$$ Ioo,000 remains constant in value during a five year period and produces 5 per cent each year. It is suggested that the life tenant and remainderman (i.e. presently, the estate) be viewed as having in fact shared $\$ 125,000$ in the ratio of 4 to $\mathrm{I}^{29}$ On this approach, if the property is unproductive there is primarily a loss of total net value. Since this loss has not been caused by either party and cannot be recouped from a wrongdoer, it is suggested that it be apportioned between the parties so that the life tenant is made to suffer a deviation from normal income in the same proportion that the remainderman is made to suffer a deviation from normal corpus. Consequently, if there is only $\$ 100,000$ instead of $\$$ I25,000 available for distribution, the $\$ 100,000$ should be shared in the ratio of 4 to $I$. For subsequent purposes ${ }^{30}$ it will be more convenient to distribute the

26 "The remainderman bears the risk of the loss attendant on the fall in the price of the capital or its depreciation." 4 Bogert, Trusts and Trustees $\$ 823$ (1935). Uniform Principal and Income Act $\S_{3}$ (2), 9 U.L.A. (Supp. 1936) 196, I99.

${ }^{27} 4$ Bogert, Trusts and Trustees $\S 822$. Goodenough v. Tremamondo, 2 Beav. 5 I2 (I840); In re Sheldon, $39 \mathrm{Ch}$. Div. 50 ( 1888 ); In re Nicholson, [rgog] $2 \mathrm{Ch}$. Irr.

${ }^{28}$ There is a suggestion of this view in Professor Bogert's work: "Wherever there is this duty to convert and reinvest in ordinary legals for the benefit of the life cestui and remainderman, there is implicitly an intent that thereby the benefits to be derived from the trust shall be standardized and equalized so that the life cestui shall get approximately the same degree of benefit from the trust as the remainderman and no more .... there is a negation of any intent that the life beneficiary shall either be starved due to temporarily unproductive property or flooded with benefits due to speculative condition," 4 Bogert, Trusts and Trustees $\S 825$ ( 1935 ).

${ }^{29}$ The concept of total net value as used herein means no more than the total value which is distributed over a given period of time. It is the value from the property not the value of the property in the sense that a cow and two calves might be said to represent the total value from the cow over a given period although the value of the cow has remained constant. Further, the remainderman is said to share this only in the sense that his part is preserved for him.

${ }^{30}$ See p. I30 infra. 
$\$ 25,000$ loss in the ratio of 4 to $I$ and then to deduct the respective shares of the loss from normal income and normal corpus. ${ }^{3 \mathrm{x}}$ This method, too, can be stated algebraically:

Let $L=$ life tenant's share of $\quad r=$ current rate of income proceeds $\quad t=$ interval of unproductivity

$R=$ remainderman's share of $x=$ life tenant's share of loss proceeds $\quad y=$ remainderman's share of loss

$P=$ inventory value

$S=$ sale proceeds

Assuming $P=S$ then, the loss $=r t P$.

$$
\begin{gathered}
x+y=r t P \\
\frac{x}{r t P}=\frac{y}{P}
\end{gathered}
$$

Solving these simultaneous equations for $x$ :

Since $x=r t P-y$

$$
x=r t y
$$

$$
\begin{aligned}
r t P-y & =r t y \\
r t P & =r t y+y=y(r t+\mathrm{I}) \\
y & =\frac{r t P}{\mathrm{I}+r t}
\end{aligned}
$$

Further, $R=P-y$

$$
\begin{aligned}
& R=P-\frac{r t P}{\mathrm{I}+r t}=\frac{(\mathrm{I}+r t) P-r t P}{\mathrm{I}+r t}=\frac{P+r t P-r t P}{\mathrm{I}+r t} \\
& R=\frac{P}{\mathrm{I}+r t}
\end{aligned}
$$

It is very striking that in a case where the property has remained constant in value, the present formula and the traditional one yield the same result although the theories used are dissimilar.

Thus, the Restatement:

Thus, the present formula:

$$
\begin{array}{rlrl}
x & =\frac{S}{\mathrm{I}+r t} & R & =\frac{P}{\mathrm{I}+r t} \\
x & =R & S & =P \\
\therefore R & =\frac{S}{\mathrm{I}+r t} & R & =\frac{S}{\mathrm{I}+r t}
\end{array}
$$

${ }^{31}$ This view would seem to be contrary to the traditional common law approach, which uniformly refuses to apportion between equal and irreconcilable claims-as witness conversion of chattels, contributory negligence and risk of loss in land contracts. See Gregory, Legislative Loss Distribution in Negligence Actions (1936). 
This is not of course a miraculous coincidence. It is fundamental to both theories to apportion in the ratio of $r t / I+r t$. It should be noted that only a proportionate amount of the normal income is restored to the life tenant. It is not clear under the traditional rationale why he should not be made whole, since the purpose of apportionment is to restore the status quo and give him delayed income..$^{32}$ But if the Restatement formula is taken as an algebraic attempt not to find out what sum etc. but rather to apportion the total value on hand in the fundamental ratio in which the two beneficiaries share, it is correct in this case.

However, this divergence in theory produces crucial differences in other cases. Thus, in a case where the property has gone up in value the traditional formula apportions the proceeds without taking any cognizance of the wellestablished rights ${ }^{33}$ of the remainderman to the increases in corpus. ${ }^{34}$ It is arguable that in this situation capital gains and losses should be apportioned. In fact, the theory that has been advocated, viz, pro rata sharing of the total value of the property as opposed to segregation of income per se to life tenant and corpus per se to remainderman might seem to compel an apportionment. Further, perhaps the best justification for not apportioning capital changes is its impracticality in the ordinary case. Thus, if property increases in value from $\$ 80,000$ to $\$ 100,000$, the gain of $\$ 20,000$ cannot be separated from the property and distributed. Here, however, the property has been transmusted into money and can be distributed in any ratio. But it is arguable that capital gains and losses adjust themselves since the income is proportionately altered; that there is no basis for determining a ratio for apportionment; and that in any case there is no more reason for apportionment of capital changes here than in the case of productive property since the basis for apportionment is simply loss of income. And whatever may be the wisdom of apportioning capital gains, it is certainly unwise to apportion a capital gain unwittingly 35 in an attempt to apportion only a loss of income. This is in effect what the traditional formula does. Under the suggested analysis the remainderman gets the benefit of the increase subject only to his proportionate reduction because of the loss due to unproductivity. Simultaneously there has been an income loss and a capital gain; the loss both parties must share, the gain only one party should receive. Algebra does not cease to afford a convenient tool.

${ }^{32}$ Subsequently in the course of his remarks, Mr. Rose made precisely this suggestion. XI Proceedings: American Law Institute 207 (I934).

${ }_{33} 4$ Bogert, Trusts and Trustees $\$ 823$ (r935); Uniform Principal and Income Act $\$ 3$ (2) 9 U.L.A. (Supp. 1936) 196, I99; Wood v. Davis, r68 Ga. 564, I48 S.E. 330 (I929); In re Packer's Estate, 29I Pa. x94, I39 Atl. 867. And see Ex parte Humbird, Ir4 Md. 627, 80 Atl. 209 (increase in value of unproductive land realized).

${ }_{34}$ Rest., Trust. No. 24I, comment c (I935).

${ }^{35}$ It is to be noted that the Restatement expressly excepts the unproductive property situation from the operation of the general rule. Rest., Trusts $\S 233$, comment (b) (I935). No reason is given for this departure from the usual rule. 
Had the property been productive it is reasonable to assume the productivity would have increased roughly in the same degree as its value increased. Hence, this factor should be considered in apportioning the loss. Consequently, the normal income is best ascertained by taking the mean between the inventory value and the sale proceeds as the principal. Instead of taking the normal trust rate on the inventory value as above to determine the loss $(r t P)$, the trust rate is taken on this mean value $[(S+P) / 2] r t$. Thus, the beneficiaries' share of the loss stated algebraically:

$$
x+y=\frac{S+P}{2} \cdot r t
$$

But $y$ as we have seen equals $\mathrm{I} /(\mathrm{I}+r t)$ times the loss.

$$
y=\frac{I}{I+r t} \cdot \frac{(S+P) r t}{2}
$$

Then the remainderman's share of the proceeds equals his share had there been no loss viz. the total proceeds (inventory value plus gain) less his share of the loss or $y$. Thus,

$$
R=S-\frac{\mathrm{I}}{\mathrm{I}+r t} \cdot \frac{S+P(r t)}{2}
$$

A numerical example will illustrate how considerable this difference may well be. Thus, consider the case in which property has increased in value from $\$ 20,000$ to $\$ 100,000$ in four years ${ }^{36}$ and the normal trust rate is $5 \%$. Under the traditional method the life tenant would get $\$ 16,667$; the remainderman $\$ 83,333.37$ Under the suggested method their respective shares would be $\$$ Io,000 and $\$ 90,000.3^{3}$ But perhaps more significant is the fact that under the traditional method the life-tenant will get $\$ 4,667$ more than he would have received had the property at all times remained productive since he would have received $5 \%$ of $\$ 60,000$ (the mean value for four years) or $\$ 12,000$, had there been no unproductivity. This result can hardly have been intended by the framers of the formula.

Where the property has decreased in value the traditional method inadvertently apportions a capital loss. And the results are equally striking. The suggested formula for the case of an increase works precisely as well here. Assuming that in the above case the property had decreased in value from $\$ 100,000$ to $\$ 20,000$, under the traditional method the life tenant will receive $\$ 3,333$; the remainderman $\$ 16,667$. Under the suggested method their respective shares will be \$10,000 and \$ro,000.

${ }^{6}$ This is not by any means an unfair case. Cf. Furniss v. Cruikshank, 230 N.Y. 495, 130

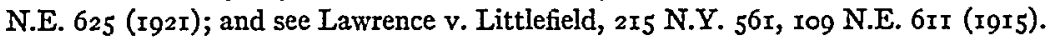

$$
\begin{aligned}
& { }_{37} x=\frac{S}{I+r l}=\frac{\$ 100,000}{I+.20}=\$ 83,333 . \\
& { }^{38} R=S-\frac{I}{I+r t} \frac{(S+P)}{2} n i=\$ 100,000-\frac{I}{I+.20} \frac{(\$ 20,000+\$(100,000) .20}{2}=\$ 90,000 .
\end{aligned}
$$


Where, as is frequently the case, the property has produced some income during its period of unproductivity, there is again a difference in result. Under the traditional method this income is deducted from what otherwise would have been the life tenant's share and is added to the remainderman's share. ${ }^{39}$ The theory apparently is that the formula yields the amount of income to which the life tenant is entitled. Hence, what income he has already received is deducted. In addition to being fictitious, this theory fails to explain why the remainderman gets this sum. Under the suggested analysis, the income which would have been produced diminished by the income actually produced is the loss to be apportioned. Restating the formula:

$$
R=S-\frac{I}{\mathrm{I}+r t} \cdot(r t P-i) \text { where } i=\text { income actually produced. } .^{\circ}
$$

The same formula applies where there has been a change in the value of the corpus and some income produced, substituting $[(S+P) / 2]$ (the mean value) for $P$. Finally, where there is some income in the hands of the trustee which has not yet been paid out the traditional method adds the amount to the sale proceeds and apportions..$^{4 x}$ It is hard to see why this case is treated differently from the above under the traditional approach. However, the result reached here is inadvertently the same result that would be obtained under the suggested formula.

A major problem in these cases has been the allocation of expenses..$^{2}$ These are generally of three types: carrying charges, sales expenses, and taxes. The traditional method deducts all of these expenses from the proceeds and apportions the remainder. ${ }^{43}$ This results in an apportionment of the expenses

${ }^{39} 4$ Bogert, Trusts and Trustees $\$ 827$ (r935); Restatement, Trusts $\$ 24 \mathrm{I}$, comment (I) (I935). It is to be noted that $\S \mathrm{II}(\mathrm{I})$ of the Un. Principal and Income Act provides that an apportionment be made only if the property produces a net income of less than one percent of its inventory value. 9 U.L.A. (Supp. 1936) r96, 20 .

$4^{\circ}$ Consider a case in which a $\$ r 2,500$ piece of property has produced only $\$ 1,000$ in 5 years. Under the traditional method the \$12,500 would first be apportioned in shares of $\$ 2,500$ and \$ro,000; the \$r,o00 would then be deducted from the life tenant's share. Thus, the life tenant would receive $\$_{I, 500}$; the remainderman $\$ I I, 000$. Under the suggested analysis, the remainderman would receive $\$ I 2,500-\frac{I}{I+.25}(\$ 3,125-\$ I, 000)$ or $\$ 10,800 ;$ the life tenant \$r,700.

${ }_{4}^{4} 4$ Bogert, Trusts and Trustees $\$ 827$ (I935); Rest., Trusts $\S 24 x$ comment (d) (I935).

${ }_{42} 4$ Bogert, Trusts and Trustees $\S 827$; Rest., Trusts $\S 240$; Brandis, Trust Administration: Apportionment of Proceeds of Sale of Unproductive Land and of Expenses, 9 N. C. L. Rev. x27, I35 (x93I); Note, 40 Yale I. J. 275 (r930); Note, 49 Harv. L. Rev. 806 (r936); Bailey and Rice, Duties of a Trustee with Respect to Defaulted Mortgage Investments, $84 \mathrm{U}$. of Pa. L. Rev. $\mathbf{5}_{57}, 330$ (1935).

43 Edwards v. Edwards, 183 Mass. 58 I, 67 N.E. 658 (I903); Rest., Trusts $\S 240$, comment (d) (I935); Bogert, Trusts and Trustees $\$ 825$ (1935). Uniform Principal and Income Act $\S$ II, 9 U.L.A. (Supp. I936). In Furniss v. Cruikshank, 230 N.Y. 495, I30 N.E. 625 (I92I) 
since apportioning the net proceeds is equivalent to apportioning separately the gross proceeds and the expenses and then deducting the shares of the latter from the shares of the former. The reason for so doing is not apparent under this approach. Normally, such expenses are deducted from income.44 If the traditional method is an attempt to find the delayed income of the life tenant, it would seem that expenses should as usual be deducted from his share.45 Of course, it is obvious that this might in many cases practically wipe out the life tenant's share and thus defeat the very purpose of apportioning, viz., to put some money in the pocket of the life tenant. Granting that there should be some apportionment of expenses because the life tenant has a reduced quota of income out of which to pay expenses, it does not follow that the above ratio is correct. In a typical case this ratio works out so that the remainderman bears the major fraction of these expenses which were formerly ex hypothesi borne roo\% by the life tenant. Thus it might plausibly be urged that when the life tenant pays the full quota of expenses he does so out of a full quota of income; consequently, where his quota of income is reduced his share of the expenses should be proportionately reduced. The results under such a method would be radically different from those now reached.

However, the above difficulty is unreal and the suggested solution is consequently unsound. The error lies in the assumption that in cases of productive property expenses are paid out of the life tenant's share and not out of the remainderman's share. Really, the life tenant's share is not the gross income per se but a normal yield of net income. Consequently, since expenses are not deducted from his net income, it is unreal to say that they are deducted from his share. In fact so long as the gross income is sufficient to pay both expenses and net income the integrity of the life tenant's share is preserved exactly to the same extent as the integrity of the remainderman's share despite the fact that expenses are paid. When gross income is not sufficient to pay both expenses and the current net income, the life tenant's share would be invaded were expenses to be paid out of it. But it is at precisely this point that a case of unproductive or underproductive property arises and there is a loss of normal net value to be apportioned. Deduction of expense can perhaps be viewed in two ways: either there is an apportionment of expenses in a given ratio regardless of whether the property is productive or unproductive or there is never an apportionment of expenses but merely an apportionment of loss of normal net value. But in neither case is there a problem of allocating expenses which is peculiar to cases

apparently the sale price less cost of sale alone was apportioned and the carrying charges were treated as permanent charges on capital. See Matter of Rowland's Estate, 273 N.Y. 100, 6 N.E. (2d) 292 (I937); Matter of Satterwhite, 262 N.Y. 339, 342, I86 N.E. 857 (I933).

44 Bridge v. Bridge, $x_{4} 6$ Mass. 373 , 55 N.E. 899 (1888); Mulford v. Mulford, 42 N.J. Eq. 68, 6 Atl. 609 (1886); Matter of Albertson, II3 N.Y. 434, 21 N.C. II7 (I889); Matter of Estate of Ardvey, 232 N.Y. 109, I33 N.E. 369 (I921).

${ }_{45}$ See Brandis, op. cit., note 42 , supra at 136 . 
of unproductive property. It should then be apparent that the suggested formula always presupposes net proceeds. Again, the traditional method happily reaches the right result.

The situation in which the life tenant dies during the unproductive interval $4^{6}$ might seem to present exceptional difficulties under the suggested rationale. Under orthodox conversion, since there is a relation back, little difficulty has been felt in allowing the estate to recover for the interval during which the life tenant lived, and allowing the next beneficiary to recover for the remainder. ${ }^{47}$ But there is no genuine obstacle to the same recovery under the theory suggested. It is not a question of the cause of action arising after the death of the life tenant; really there is no cause of action against the trustee, there is simply his problem of apportioning a loss which occurred due to unproductivity. Since part of this loss was suffered by the life tenant, while he lived, there is no reason for not compensating his estate.

The major piece of legislation on the problem, the Uniform Principal and Income Act, contains a provision deserving of special comment. The act provides that the life tenant's apportioned share should not exceed the amount by which the net proceeds exceed the inventory value..$^{8}$ The effect of this proviso is to apportion only where and to the extent that the property has increased in value; that is, at all times the original corpus is preserved intact for the remainderman. Since, as has been pointed out, it is unusual for unproductive property to increase in value, this proviso greatly reduces the scope of the act. Perhaps, the most charitable explanation of this provision is the assumption, taking the traditional theory literally, that the delayed income has somehow gone into the land and resulted in the increase in value. Again it may represent a concession to the settlor's intent that the corpus remain intact. But however explained, the proviso strikes a curious compromise. Thus, under the act capital changes are apportioned, but under the proviso they are not completely apportioned. And thus while a minimum corpus is assured to the remainderman, the corpus per se is not. It is submitted that the proviso acts as a check but an inexplicable check on some of the errors which would result from a more consistent adoption of the theory embodied in the act.

Although the case of a defaulted trust mortgage has been treated as unproductive property in current discussion, the case deserves some special comment. ${ }^{49}$ The factual set-up is quite similar to that in the above cases. The un-

${ }_{46}$ Brandis, op. cit., note 42, supra at ${ }^{3} 34$.

${ }^{47}$ Matter of Pinkney, 208 App. Div. I8I, 202 N.Y. Supp. 8I8 (I924) aff'd 238 N.Y. 602, I44 N.E. 909 . Contra, Ogden v. Allen, 225 Mass. 595, II4 N.E. 862 (Igr7).

${ }^{4} 8$ Uniform Principal and Income Act $\S$ I I (2), provides ". . . in no event shall such income be more than the amount by which the net proceeds exceed the fair inventory value of the property or in default thereof its market value at the time the principal was established as to cost where purchased later." See Brandis, op. cit., note 42, supra, I27, I36.

49 There has been a good deal of discussion on this point. See Bailey and Rice, op. cit. note 42, supra, 178, 327, 625; Brandis, op. cit. note 42, supra, 127; 138; 49 Harv. L. Rev. 805 (1936); Rest., Trusts $\S 24 \mathrm{I}$, comment (b) (I935); $c f$. Bogert, Trusts and Trustee $\S 820$ (I935). 
productivity results from a failure on the part of the mortgagor to pay interest or principal. In the typical case it is some time after default before the trustee forecloses and buys in, and finally it is some time after foreclosure before he sells the property; the question of equitably distributing these proceeds then arises.

In a large majority of cases these proceeds have been apportioned not by finding what sum if invested etc..$^{50}$ but by comparing the amount due on the interest to the amount due on the principal.sx In case there is a sale to an outsider at foreclosure the propriety of this result is clear since the security is as much security for the interest owed the life-tenant as it is for the principal owed the remainderman. However, where the trustee buys in at foreclosure and only after a period of years sells to an outsider, a whole hearted adoption of the mortgage theory leads to a very complex problem. Thus, if the security is security for both, the trustee must have bought in the land for both and thus the life tenant has become a pro-rata owner of the land. He is also life-tenant of the estate's share. In the light of this double position of the life-tenant, a careful analysis of three problems is required: rate, changes in capital, and distribution of whatever income is produced.

There has been much discussion ${ }^{52}$ as to whether the rate at which the lifetenant's share is to be estimated should be the mortgage rate for the interval between default and sale; the trust rate for the interval between default and sale; or the mortgage rate only for the interval between default and foreclosure and the trust rate thereafter. Since the mortgagor has a fixed obligation to pay interest at the mortgage rate until foreclosure, a strict application of mortgage theory would require that the life-tenant's share be computed at this rate until foreclosure. But when the trustee buys in, the beneficiaries become co-owners of the land in the ratio that the amount of interest due until default bears to the amount of principal due. It is clear that after foreclosure, there is simply a case of unproductive realty and the life-tenant's share should be computed at the normal trust rate. However, he is entitled to income from the estate's share only; he is of course not entitled to be compensated for the loss of income on the share he owns outright. Hence, although the trust rate would be used, it would be used on a reduced principal. A numerical example will illustrate this point. Assume a $\$ 100,000$ principal debt outstanding; $3 \frac{1}{3}$ yrs. interest owed at $6 \%$ until foreclosure; and that the propery is unproductive for 3 years after foreclosure and is finally sold for $\$ 100, \infty 00$. It is suggested that at foreclosure, the beneficiaries become co-owners in the ratio of $\$ 10,000$ to $\$ 100,000$, that is, the lifetenant would own one-sixth of the property outright; the estate the other fivesixths. The life-tenant is entitled to be compensated for loss of income on the

so Roosevelt v. Roosevelt, 5 Redf. (N.Y.) (I88r); Greene v. Greene, Ig R.I. 6rg (I896). See also Cox v. Cox, L.R. I869 8 Eq. 343; Parsons v. Winslow, I6 Mass. 36r (I820).

${ }_{53}$ Matter of Chapal, 269 N.Y. 464 , I99 N.E. 762 (1936); In re Moore, 54 L. J. Ch. (n.s.) 432 (1885); Hagan v. Platt, 48 N.J. Eq. 206, 21 Atl. 860 (1891); Meldon v. Devlin, 31 App. Div. I 46,52 N.Y. Supp. 172 (I898), aff'd on opinion below, 167 N.Y. 573,60 N.E. III6 (I900). 52 See 49 Harv. L. Rev. 805 (1936). 
estate's share; there remains then simply a problem of apportioning the loss due to the three year unproductivity of five-sixths of the property. This of course should be solved in the manner indicated above.53

It should be apparent from what has been said how capital gains or losses should be treated. The life-tenant properly gets the benefit of the increase and bears the burden of the decrease in the share he owns outright. And as to the estate's share, there is again simply a problem of unproductive property coupled with an increase or decrease in corpus. And finally the distribution of whatever income has been produced follows the same pattern.

It has been strongly urged that the mortgage cases should be treated in all respects simply as cases of unproductive realty and the traditional method applied to both. ${ }^{54} \mathrm{It}$ is true that the literal mortgage theory does lead to rather fine spun results when fully and consistently spelled out. Further, it can be argued with some force that foreclosure is only an incidental step and that it is the ultimate sale to an outsider that is really important. On the other hand it seems somewhat peculiar to ignore the well-established characteristics of a mortgage simply for the sale of convenience. In any event if mortgage theory is adopted it should be consistently carried out; if the mortgage element is ignored, the suggested rather than the traditional method of apportioning the proceeds from the sale of unproductive realty should be employed.

53 See p. r3I supra.

${ }^{54} 49$ Harv. L. Rev. 805 (I936). Rest., Trusts $\S 24$ r, comment (b) (I935). 